\title{
A DIGITALIZÁCIÓ SZEREPE A FOLYAMATFEJLESZTÉSBEN
}

\author{
Matyi Henriett \\ hallgató, Miskolci Egyetem, logisztikai mérnök MSc, e-mail: matyi.henriett@gmail.com \\ ${ }^{2}$ Cím: 3515 Miskolc, Miskolc-Egyetemváros, Logisztikai Intézet \\ Tamás Péter \\ egyetemi docens, Miskolci Egyetem,Logisztikai Intézet, e-mail: alttpeti@gmail.com \\ ${ }^{2}$ Cím: 3515 Miskolc, Miskolc-Egyetemváros, Logisztikai Intézet
}

\begin{abstract}
Absztrakt
Napjainkban a negyedik ipari forradalomban élünk, amely számos lehetöséget hordoz magában, ilyen például az intelligens gyár, valamint a dolgok internete. Emberek, gépek, termékek kapcsolódnak egymáshoz hálózat segitségével, amely eltörli a határvonalat a fizikai, digitális és biológiai szférák között. A digitális forradalom nemcsak megváltoztatta a vállalkozások felfogásának módját, hanem növelte teljesitményüket is. A mai korban a vállalkozás minden aspektusát a müveletektöl a vezérlésekig digitális eszközökkel szabályozzák. Az ilyen digitális átalakulások minden iparágat megváltoztattak és forradalmasitottak. A cégek javitották az üzleti versenyképességüket és elöre mozditották magukat a piacon. A digitális átalakulás több új lehetöséget is meg tud nyitni a vállalatok életében, amire az egyedi tömeggyártások során szükségük lehet. Az átalakulás egy új gondolkodásmódot igényel. Kutatásomban több lépésen keresztül bemutatom, hogyan lehet a digitalizációt bevezetni egy cég életébe, elönyeivel és hátrányaival. Dolgozatomban egy általam megalkotott cég példáján keresztül mutatom be a digitalizáció alkalmazásának egyik lehetőségét, valamint dolgozatom végén kitérek arra, hogy milyen költségeket kell figyelembe venni, és mennyi idö múlva fog megtérülni a javasolt befektetés.
\end{abstract}

Kulcsszavak: Digitalizáció, Lean 4.0, Ipar 4.0, Logisztikai kutatás

\begin{abstract}
Today, we are living in the Fourth Industrial Revolution, which offers many opportunities, such as the smart factory and the Internet of Things. People, machines, products connect with each other through a network that blurs the boundary between the physical, digital and biological spheres. The digital revolution has not only changed the way businesses perceive themselves, but also increased their performance. Today, every aspect of a business, from operations to controls, is controlled by digital devices. Such digital transformations have changed and revolutionized every industry. Companies have improved their business competitiveness and moved forward in the market. The digital transformation can open up many new opportunities in the life of companies that individual mass production needs. Transformation requires a new way of thinking. In my research, I will show you how to introduce digitalisation into the life, advantages and disadvantages of a company through several steps. In my dissertation, I present an example of the application of digitalization through the example of a company I created, and at the end of my dissertation I discuss what costs should be considered and how long the proposed investment will return.
\end{abstract}

Keywords: Digitalization, Lean 4.0, Industry 4.0, Logistics Research 


\section{Bevezetés}

A világ, amiben élünk gyorsabban változik, mint valaha. A dolgok internete, mobilitás, Big data, virtuális- és kiterjesztett valóság, valamint a közösségi média a digitális ügyfél kötelezettség és az IT alapú üzleti folyamatok, a termékek és szolgáltatások következő szintjére vezette a vállalatokat. Szinte minden iparágban a digitális technológiák példátlan átalakulást idéznek elö, munkánkat és életünket olyan módon változtatják meg, amire eddig soha nem számítottunk. Kutatómunkám célja a digitalizáció adta lehetőségek kihasználása. Egy olyan felületet hozok létre, ahol minden vállalat a saját adataival kiegészítve használni tudja az általam elkészített vizsgálati modellt. A kutatásomban egy általam meghatározott cég adatai alapján mutatom be a folyamatokat, költségeket, valamint ezek megtérülését. Ahhoz, hogy az adatok minél valósághübbek legyenek kérdőív segítségével és annak kiértékelésével határoztam meg azokat. Célom bemutatni, hogy a digitális eszközökkel milyen hatékonyságnövelést tudunk elérni munkahelyünkön elsősorban a megtakarított idő vonatkozásában

\section{Esettanulmány bemutatása}

A kutatómunkám célja, egy olyan költség-kalkuláció készítése, amit minden cég a saját adataival el tud látni és testre tud szabni, ezáltal saját vizsgálati eredményt tud kapni.

\subsection{Vizsgált fiktív vállalat szervezeti felépítése}

A vállalat felépítését tekintve összesen 1001 főből áll.

Ennek a szervezeti felépítését a következő:

- Igazgató 1 fö

- Felsővezető 20 fö

- Középvezető 70 fö

- Csapatvezető 140 fö

- Alkalmazott 770 fö

\subsection{Kérdőív értékelése}

A dolgozatban bemutatásra kerülő kutatómunka célja, egy olyan vállalat felépítése, ahol a digitális eszközök adta lehetőségeket teljes mértkében kihasználják, mind az alkalmazottak és a vezetők. A jelenlegi helyzetek felmérésére kérdőív formájában történt, valamint a válaszok alapján kidolgozásra került egy lehetséges digitálisan fejlett vállalatot. A kérdőíves felmérésre összesen 139 válasz érkezett. Az első kérdés a jelenlegi munkahely típusok felmérése irányult, valamint hol szeretnének dolgozni majd a jövőben. Az eredményböl látható, hogy a kitöltők 30\% egy multinacionális vállalatnál dolgozik vagy dolgozna szívesen. Ez alapján az általam kitalált fiktív vállalat szintén multinacionális. Napi munkavégzés során használt digitális eszközökről a következő diagram készült el a kitöltők válaszai alapján (1. ábra).

Beosztások szerint céges mobiltelefon használatának százaléka a következőképpen alakul:

- Felső vezetők $100 \%$

- Közép vezetők $100 \%$

- Csapatvezetők $100 \%$

- Alkalmazottak $61 \%$ 


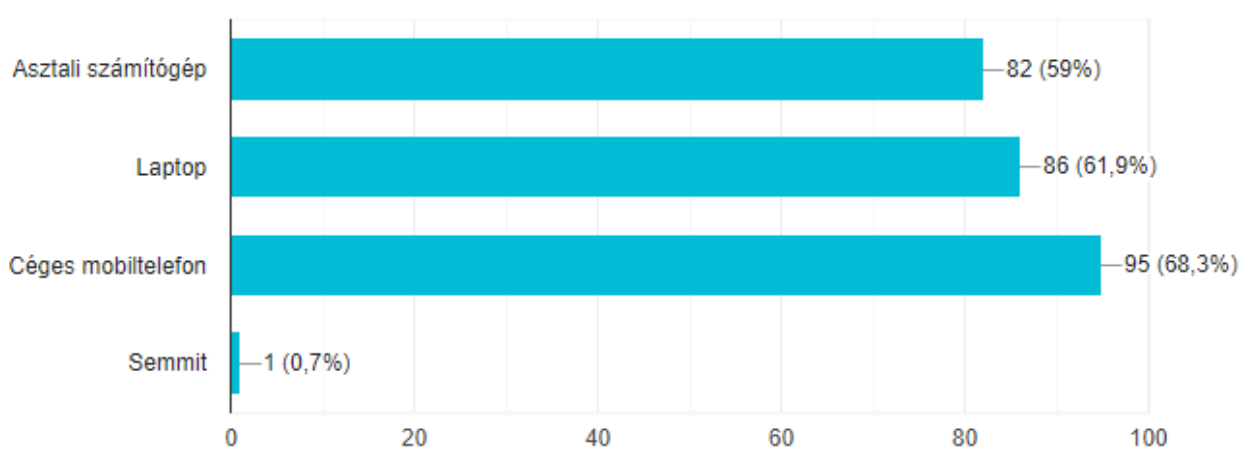

1. ábra Kérdőiv 3. kérdése (saját szerkesztés)

Mobiltelefon típusának a meghatározásához szintén figyelembe vettem a kérdőívemet. A kérdőívet kitöltők alapján a legtöbben az Apple készülékeket választották. Ez a további számításoknál fontos adat, hiszen az Apple katalógusából választottam készülékeket. A következő kérdés a céges mobiltelefon alkalmazásainak használatára irányult. A válaszadók alapján a telefonos alkalmazások közül a következőket használnák (2. ábra):

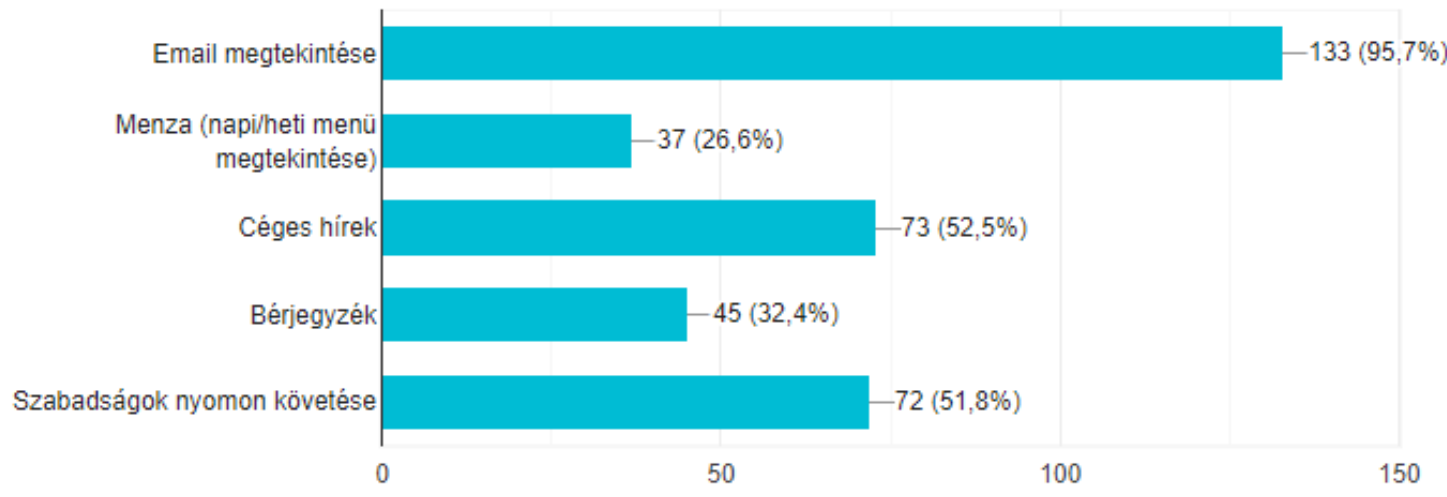

2. ábra Kérdöiv 6. kérdése (saját szerkesztés)

\section{Elvégzett vizsgálatok eredményei}

A fentebb említett alkalmazásokkal a nap folyamán szabad perceket lehet megtakarítani. Ezáltal az email megtekintéséhez nem kell bekapcsolni a számítógépet vagy laptopot, hanem elég a telefonról megtekinteni azt. A digitális eszközökkel való időmegtakarítást 10 ismerősömmel mértem le.

Az eredmények kiszámításához a KSH adatai alapján számítottam az átlagos havi béreket._A KSH 2019. augusztusi adatai alapján az átlagos nettó kereset 239300 Ft. Az elkészült számítások alapján az alkalmazottak ennek az összegnek a 90\%-át kapják, csapatvezetők $120 \%$, közép vezetők $180 \%$, míg felső vezetők $300 \%$-ot. [1] 
1. táblázat Alkalmazások használatának ideje (saját szerkesztés)

\begin{tabular}{|c|c|c|}
\hline Laptopról & Alkalmazás megtekintése & Mobiltelefonról \\
\hline $862 \mathrm{sec}=13,7 \mathrm{~min}$ & E-mail megtekintése & $372 \mathrm{sec}=5 \mathrm{~min}$ (napi 5 alkalom) \\
\hline $\begin{array}{c}31,3 \mathrm{sec} \\
342,6 \mathrm{sec} \text { (sétaidő) }\end{array}$ & Menza megtekintése & $\begin{array}{l}9,3 \mathrm{sec} \text { (napi } 1 \text { alkalom) } \\
18,2 \mathrm{sec} \text { ( } 2 \text { étkezés) }\end{array}$ \\
\hline $52,6 \mathrm{sec}$ & Céges hírek megtekintése & 18,6 sec (napi 2 alkalom) \\
\hline $\begin{array}{c}31,3 \mathrm{sec} \\
321,3 \mathrm{sec} \text { (sétaidő) }\end{array}$ & $\begin{array}{l}\text { Bérjegyzékek, szabadságok, } \\
\text { beosztások nyomonkövetése }\end{array}$ & $\begin{array}{l}9,3 \mathrm{sec} \text { (napi } 1 \text { alkalom) } \\
9,3 \mathrm{sec} \text { (napi } 1 \text { alkalom) }\end{array}$ \\
\hline
\end{tabular}

Átlag havi bérek:

- Felső vezető: $717900 \mathrm{Ft}$

- Közép vezető: $430740 \mathrm{Ft}$

- Csapatvezető: $287160 \mathrm{Ft}$

- Alkalmazott: $215370 \mathrm{Ft}$

Ezeket az átlagbéreket módosíthatják más cégek a nekik megfelelő adatokra.

Összes megtakarított költség és idő ezekkel az alkalmazásokkal így alakul:

Laptoppal rendelkező dolgozó esetén:

- Napi időmegtakarítás: $10 \mathrm{~min}$

- Havi időmegtakarítás: $\sim 4 \mathrm{~h}$

- Havi költségmegtakarítás: $1600000 \mathrm{Ft}$

Laptoppal nem rendelkező dolgozó esetén:

- Napi időmegtakarítás: $\sim 15 \mathrm{~min}$

- Havi időmegtakarítás: $\sim 5 \mathrm{~h}$

- Havi költségmegtakarítás: $\sim 5000000 \mathrm{Ft}$

\section{Telefon választás}

A számítások eredményeként kétféle telefonkészülék került kiválasztásra. Egy alapkészüléket, amit mindenki megkap, és egy felső kategóriás készüléket, amit a vezetők havi díj ellenében választhatnak. Alap kategóriás telefon [2]: Iphone 6S, $119900 \mathrm{Ft}$

Felső kategóriás telefon [3]: Iphone XS, $359900 \mathrm{Ft}$

Ezt követően 3 Scenáriót határoztam meg:

I. Scenárió: Minden dolgozó az alapkészüléket választja: $119900000 \mathrm{Ft}$

II. Scenárió: Vezetők fele választ prémium kategóriás telefont: $133711500 \mathrm{Ft}$

III. Scenárió: Minden vezető prémium kategóriás telefont választ: $175100000 \mathrm{Ft}$ 
Az első scenárió lenne a legkedvezőbb befektetés a cég számára, mivel ez esetben a vezetők közül mindenki az alapkészüléket választaná. A második scenárió egy reálisabb esetet mutat be, hiszen itt a vezetők fele prémium kategóriás telefont választana, míg a harmadik esetben minden vezető prémium kategóriás telefont választana, ezáltal megnövekedne a cég digitalizációba történő befektetésének az összege. Elkészítésre került egy költség megtérülési idő diagramot, amiről leolvasható mind az olcsóbb, mind a drágább termékekkel a megtérülés ideje. A telefonok befektetése 2019. decemberében kezdődne meg, így ehhez viszonyítva láthatóak az eredmények (3. ábra). A diagramok nem a bevételt mutatják, hanem a megtakarított idővel arányos megtakarított költséget, ami az idő nyereségből következik.

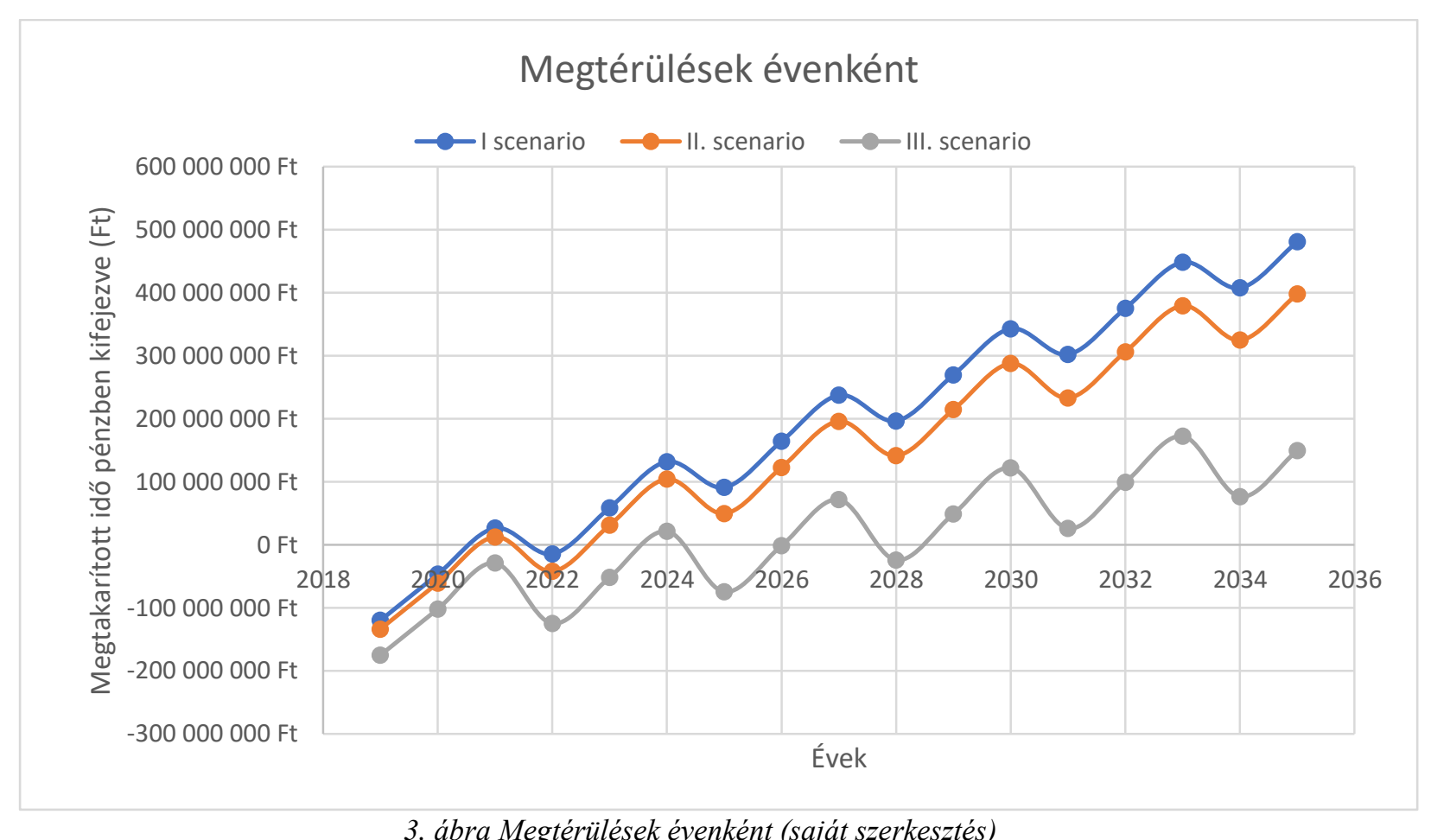

Több tényező figyelembevételével is megvalósult, melyek a:

- Fluktuáció mértéke éves szinten. Ehhez 10 \%-ot határoztam meg, így esetemben évenként 100 ember cserélődését jelenti.

- Telefon amortizáció $\rightarrow 3$ évente 1000 db új készülék vásárlása minden dolgozó részére.

- A fluktuációból következő felesleges telefonok eladása féláron, ez jelen esetben $100 \mathrm{db}$ készüléket tartalmaz.

Jól látható a diagramon is, hogy az első és harmadik scenárió közötti különbség hatalmas, hiszen jelen esetben a vezetők mind az alapkategóriás készüléket mind a prémium kategóriás készüléket választhatják további költségek nélkül.

Mivel így nagyon sokára térülne meg a prémium kategóriás készülék ára, ezért erre a problémára bevezetésre került SOLVER programot az Excel táblában. Felvetettem, hogy a spórolás a 15. évet 
követően egyezzen meg mind az alapkategóriás, mind a prémiumkategóriás készüléknél. Így amelyik vezető a prémiumkategóriás készüléket választja, annak lesz havi díja, ezáltal közel egyszerre térülne meg a kétféle készülék. A SOLVER program használatát követően ez az összeg felső kategóriás készülék esetén havi $7500 \mathrm{Ft}$-ot jelentene. A megtérülési idő diagram a 4. ábra szerint alakul.

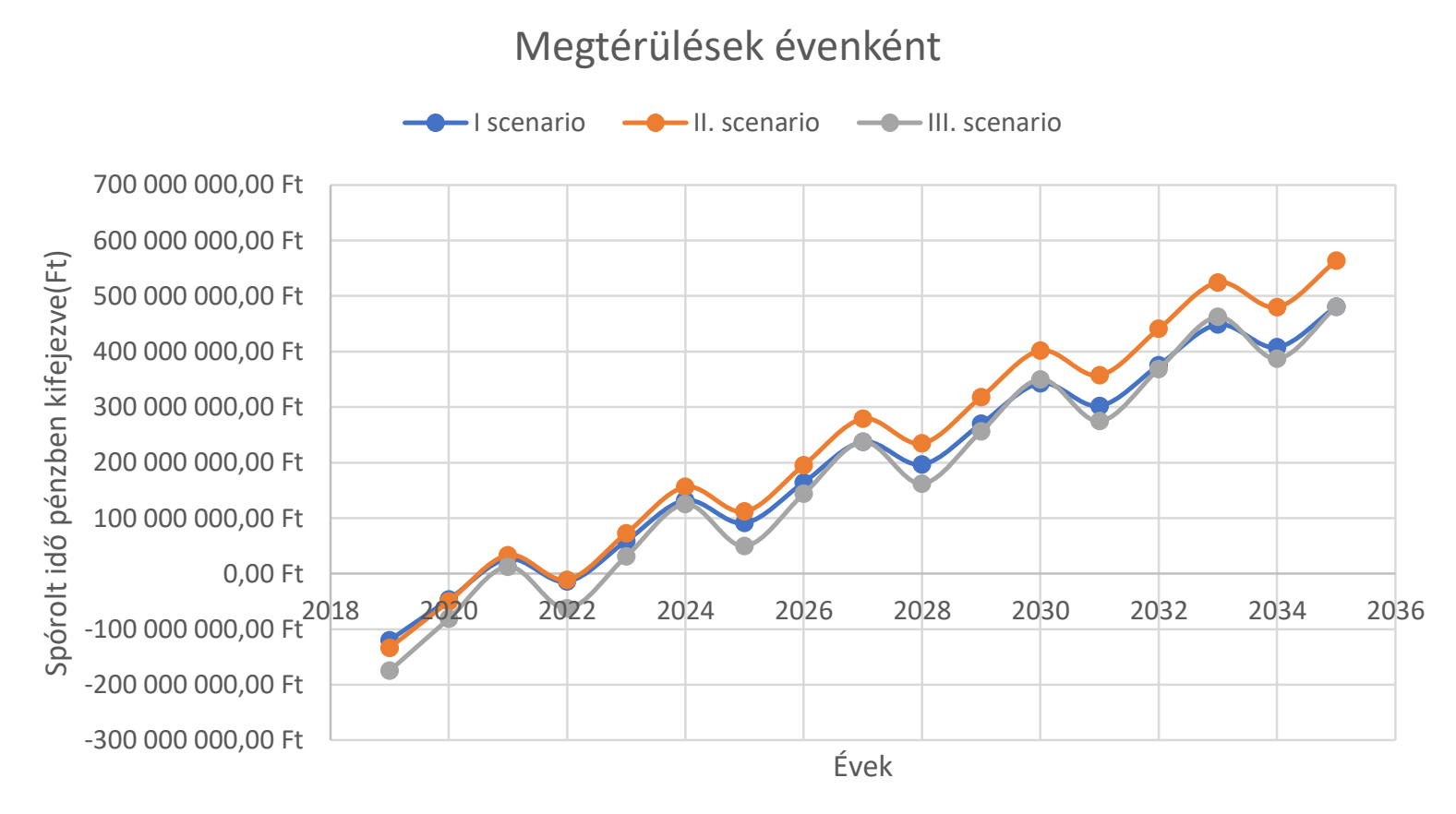

4. ábra Megtérülések éves szinten, pénzbefizetésekkel (saját szerkesztés)

Ebben az esetben szintén figyelembe vettem a fluktuációt, a telefon amortizációt, valamint a fluktuációból következő felesleges telefonok eladását az előző leíráshoz hasonlóan.

A diagramon jól látható a megtérülése a scenárióknak 2021. év. Bár ezt követően a 2022. év végével 1000 db új készüléket kell vásárolni, ezért újra negatív intervallumba kerülnek a görbék. A diagramon megfigyelhető, hogy az első és harmadik (kék és szürke görbe) scenárió 2035. évre ugyan akkora megtérülést fog hozni.

\section{Kidolgozott módszer ismertetése}

A kutatási eredmények alapján alapvetően bármelyik cég saját profiljára meg tudja alkotni ezeket a számításokat. Ebben a fejezetben bemutatásra kerül a vizsgált digitalizáció bevezetése egy általánosított esetben.

1. Igény felmérés (dolgozói kérdőív)

2. Piacon tájékozódni az aktuális mobiltelefon készülékekről (Alap eset + Prémium eset)

3. Számításhoz szükséges adatok összegyüjtése (létszám, fluktuáció, órabér stb.)

4. Excel kezelöfelület kitöltése

5. Eredmények megtekintése 
Első lépésként a dolgozói igény felmérése alapján lehet meghatározni, hogy milyen készülékre van szükségük. Ezt követően, amint a mobiltelefon típusát meghatározták a piacon kell tájékozódni a költségekről. A számítások vezetőkre és alkalmazottakra egyaránt elvégzésre kerültek. A vezetőknek lehetőségük van prémium kategóriás készülékek választására, ezért náluk újabb felmérésre van szükség az igények meghatározásához. Számításhoz különböző adatokat kell összegyüjteni, ezek a létszám, fluktuáció, órabér stb. Amint ez is megtörtént, ki kell tölteni az Excel kezelőfelületet az adatok megadásával. A kitöltött felület után azonnal megjelennek az eredmények, mint konkrét számok, mint diagramok formájában. Optimalizálni lehet havi költségekre a prémium kategóriás készülékek választásánál.

\section{5. Összefoglalás}

A cikkben ismertetett kutató munka a Miskolci Egyetem Logisztikai Intézetének Tudományos Diákköri versenyére elkészített dolgozatom kivonata. Az elvégzett kutatás célkitüzése a digitalizáció folyamatfejlesztésben betöltött szerepének érzékeltetése volt. Létrehozásra került, egy olyan Excel adattábla, melyet valamennyi vállalat a saját egyéni elképzelései szerint tud alkalmazni elöre definiált adatmezők kitöltésével. A dolgozatban egy fiktív cég alapján kerültek bemutatásra a folyamatok, költségek, valamint azok megtérülési számításai. Az elkészített munka további kutatás alapjául szolgálhat.

\section{Köszönetnyilvánítás}

„A cikkben/előadásban/tanulmányban ismertetett kutató munka az EFOP-3.6.1-16-2016-00011 jelü „Fiatalodó és Megújuló Egyetem - Innovatív Tudásváros - a Miskolci Egyetem intelligens szakosodást szolgáló intézményi fejlesztése" projekt részeként - a Széchenyi 2020 keretében - az Európai Unió támogatásával, az Európai Szociális Alap társfinanszírozásával valósul meg."

\section{Felhasznált források}

[1] https://istyle.hu/apple-iphone-6s.html?config_model=1324\&color=481 Letöltés: 2019.11 .02

[2] https://istyle.hu/iphone-xs.html?config_model=1323\&color=482 Letöltés: 2019.11 .02

[3] https://www.ksh.hu/gyorstajekoztatok/\#/hu/document/ker1908_Letöltés:2019.11.01.

[4] Bányai, T., Bányainé, T. Á., Illés, B., Tamás, P.: Ipar 4.0 és logisztika, Miskolc, Magyarország: Miskolci Egyetem (2019), 160 p., ISBN: 97896335818277

[5] Nagy, J: Az ipar 4.0 fogalma, összetevői és hatása az értékláncra, Budapest, Magyarország: Budapesti Corvinus Egyetem (2017), 57 p.,

[6] Tamás, P., Illés, B., Dobos, P., Seres, L.: Lean logisztika I, Miskolc, Magyarország, Miskolci Egyetem (2018), 102 p., ISBN: 9789633584742

[7] Tamás, P.: Lean 4.0 előadás, Miskolc, Magyarország: Miskolci Egyetem (2019)

[8] https://auriga.com/blog/2016/digital-transformation-history-present-and-future-trends/ Letöltés: 2019.11.02. 